James E. Campbell*

\title{
The Miserable Presidential Election of 2012: A First Party-Term Incumbent Survives
}

\begin{abstract}
This article examines the influences on the 2012 presidential election that led to the closely decided re-election of Barack Obama. Partisan parity, ideological polarization, a hyper-competitive campaign, and approval ratings for the incumbent, plus pre-convention preference polls that were evenly split, were strong signs that the 2012 presidential election would be close. The economic record of the Obama presidency, however, favored the election of Republican challenger Mitt Romney. On the other hand, President Obama had the advantages of a first partyterm incumbent, and this first party-term advantage was the major reason for President Obama's reelection. As a first party-term president, fewer voters blamed President Obama for the nation's economic problems than blamed his predecessor. Of the 12 first party-term incumbent presidents to seek reelection since 1900, 11 won and only one lost. The election of a new presidential party is tantamount to electing a president to an 8-year term.
\end{abstract}

*Corresponding author: James E. Campbell, Department of Political Science, 520 Park Hall, Buffalo, NY 14260, USA,

E-mail: jcampbel@buffalo.edu

\section{Introduction}

With the final votes cast on November 6, 2012, the 57th election of a president of the US mercifully came to a close. President Barack Obama was elected to a second term. He received $52.0 \%$ of the national two-party popular vote (332 electoral votes) to $48.0 \%$ (206 electoral votes) for his Republican opponent, former Governor of Massachusetts Mitt Romney. Of the 28 other presidential elections held since 1900, 22 (79\%) were won by wider popular vote margins and only six (21\%) were closer.

Before each presidential election, it has become something of a custom for political commentators and journalists to hail it as critical, crucial, momentous, a turning point in the nation's history. Following the election, the process is celebrated. After the red and blue maps have stopped flashing, audiences are told in election re-caps that democracy has again worked, that the people have spoken. These and other sobering bromides are part of ritualistic civic sermon that brings each election's story to its close - the political version of "they lived happily ever after." To give you fair warning, the conclusions of the analysis that follows breaks from this mold. No political fairytale here.

\section{A Miserable and Unimportant Election}

By my reckoning - and I am taking the unorthodox approach of stating my conclusions before presenting the analysis on which they are based - the 2012 presidential election was a miserable event and, as presidential elections go, unimportant. It was miserable and unimportant beyond the fact that it was interminably long, unrelentingly negative, often issue-avoidant and silly, and after inflicting so much annoying noise and expending so many billions, it left the status quo intact in both the presidency and Congress. In a more important sense, however, 2012 was a miserable election because it was a choice between two candidates each of whom by historical metrics should have lost the election.

For his part, judging by previous elections, President Obama had an economic record during his term and into the election year that appeared to make him unelectable. He had been elected 4 years earlier in the midst of the Wall Street Meltdown. The financial crisis of 2008 sent the economy into a tailspin. Voters turned away from President George W. Bush and Senator John McCain, the Republican presidential candidate in that election, and to the Democrats and then-Senator Barack Obama, to pull the economy out of the recession and get it back on its feet. That was President Obama's mandate.

Two years into his term, and over a year after economists had declared the recession to be over, the economy was still in bad shape. The mandate was unfulfilled. Voters sent President Obama and his fellow Democrats a stern message in the 2010 midterm election. Democrats lost 64 seats and their majority in the US House, the biggest loss for either party in over 60 years. After another 2 years, the economy was still sputtering. Unemployment in 2012 was very high, economic growth low, and there were scant signs of significant improvement. These economic realities were not lost on the voters. Polls showed 
that Americans understood that the economy near the end of President Obama's term was still very weak.

On the other side was Mitt Romney. Though successful in business, in directing the 2002 Winter Olympics in Salt Lake City, and in having run and won the governorship in the liberal Democratic state of Massachusetts, conservative Republicans strenuously resisted Romney's nomination. They read his record as one of moderation and vacillation, not steadfast principled conservatism. Their dissatisfaction led to their serial support for a lengthy list of non-Romney alternatives (including Perry, Cain, Gingrich, and Santorum). A large segment of the Republican base gravitated to the Anyone-But-Romney candidate du jour.

It was not until after 36 primaries and caucuses (April 10, 2012) that Romney topped $40 \%$ among Republicans in the Real Clear Politics average of preference polls for the nomination (Real Clear Politics 2012). Ultimately, his superior financing and Super PAC support, funding negative ad blitzes at the most threatening nomination opponent of the time, along with serious flaws in each of his nomination rivals, left Romney with the nomination. It was not an easy, bruise-free, or inspiring trip, however, to the Republican convention.

The battering that Romney sustained on the way to his party's nomination was hardly the greatest obstacle to his election, however. Whether he or his advisors or the sea of political pundits understood it or not, Mitt Romney faced in 2012 one of the greatest challenges in American presidential politics, the challenge of defeating a first party-term incumbent president. A first party-term incumbent is one who succeeded a president of the opposite party. In winning the 2008 presidential election, Barack Obama and the Democrats replaced George W. Bush and the Republicans. President Obama thus became a first party-term president, and they are extremely difficult to beat.

First party-term presidents have numerous advantages over their opponents, and the public rather routinely reelects them to a second term 4 years later. As drastic as it may sound, setting aside the rare case in which a first party-term president's record is magnificently awful, first party-term incumbents are elected to what is tantamount to an 8-year term. The electoral record is that impressive. Of the 12 first party-term presidents seeking reelection since 1900, 11 have won and only one has lost.

If Obama faced a near-certain loss because of his weak economic record, then, Romney faced the same grim fate because of incumbency. By one standard or another, 2012 would make history. Either a president would win with an economic record that voters in the past would have found unacceptable, or a challenger, battered in his own party's nominating contest, would complete the monumental task of defeating a first party-term president. As we now know, incumbency won out over the economy.

The 2012 presidential election was not only miserable, pitting two candidates who should have lost by historical precedents. It was also relatively unimportant. Its lack of importance goes well beyond the fact that it left the political status quo intact. All presidential elections are important in that they elect someone to the single most powerful office in the government. Yet most presidential elections go on to reveal something more about the voters' judgments of the direction of national policy. Presidential elections are normally won or lost because voters judge the performance of the in-party to have been acceptable (deserving of reelection) or unacceptable (deserving of defeat), or because they regard one candidate to better reflect their values and political principles.

The 2012 presidential election, because it turned on the first party-term incumbency advantage (as we will see shortly), reflected neither judgments about the performance of President Obama nor whether he or Mitt Romney better represented the electorate's values. The election was not a vote of confidence in the Obama administration's handling of the economy (its mandate from 2008) nor was it an indication that voters favored Obama to Romney with respect to their values. Even though it reelected President Obama, the electorate tilted more conservative than liberal. The 2012 presidential election was less about the president's performance or record and less about the value preferences of voters than it was about a systemic advantage, the first party-term incumbency advantage.

President Obama was elected to a second term in the White House despite his economic record and despite his ideological orientation, not because of either. He was elected because, as a first party-term incumbent, a large majority of voters did not blame President Obama for the nation's continuing economic stagnation. They blamed his predecessor, former President George W. Bush. In addition, as a first party-term president, President Obama received more of the benefit of the doubt from voters. Mitt Romney bore the burden of proof to make the case that President Obama was so unacceptable as president that he should not be given more time. In the end, a narrow majority of voters were not quite convinced that President Obama had crossed that line.

With the conclusions stated, we now turn to the evidence behind them. 


\section{Here's What Happened ${ }^{1}$}

Presidential elections are largely shaped by a set of fundamental political conditions in place before general election campaigns begin. These include the electorate's political predispositions (partisanship, ideology, and pre-campaign views about the issues and candidates) as well as national and political conditions (incumbency, the economy, and other circumstances) that voters might react to over the course of the campaign (Campbell 2008). While unanticipated campaign and non-campaign events may also affect the course a campaign takes, they generally do not make a big difference overall. It is easy to get trapped into thinking that every twist and turn in a campaign is significant, and while some are, most are not. To focus on the campaign as a series of events is to miss the forest for the trees. The fundamentals normally provide the structure to elections and they did so once again in 2012.

\section{A Fundamentally Close Election}

The overall context of the 2012 presidential election set the stage for a closely fought contest. Presidential elections have always been highly competitive, but they have become even more so in recent decades. There are several reasons for this. First, partisanship is near parity. Among voters in the last few elections, the percentage of Republican Party identifiers nearly equaled the percentage of Democratic Party identifiers. According to the National Election Studies for 2004 and 2008, averaged after adjusting for vote choice and turnout, about $48 \%$ of voters were Democrats and 46\% were Republicans (Campbell 2010).

Second, the electorate has also become more polarized in recent years as well. Fewer voters occupy the political center (Abramowitz 2010). Moreover, ideological orientations have become more highly correlated with partisanship (Abramowitz and Saunders 1998). Liberal Republicans and conservative Democrats are endangered species. With reinforcing partisanship and ideology, more liberal Democrats find it unthinkable to vote for a conservative Republican and vice versa. The polarized parity of partisans means that fewer voters are really movable in an election.

The 2012 presidential election was also likely to be close because of the campaign. Presidential campaigns have always been highly competitive events, with two fairly evenly matched campaign efforts. In recent elections, this has become even more so as more and more money was attracted to the process on both sides and as

1 With apologies to Adrian Monk.
Table 1 Closeness of presidential elections, 1960-2012.

\begin{tabular}{lrr}
\hline Election outcome & \multicolumn{2}{c}{ Years of presidential elections } \\
\cline { 2 - 3 } & 1960-1984 & 1988-2012 \\
\hline Mean winning vote & 55.6 & 52.7 \\
Elections won with 55\% or more & 4 of 7 & 0 of 7 \\
Largest winning vote & $61.8(1972)$ & $54.7(1996)$ \\
\hline
\end{tabular}

the presidential candidates opted out of the restrictions placed on them by the campaign financing system. This was all ratcheted upwards in 2012 as each side spent more than a billion dollars on its campaign, several hundred millions more than had been spent in 2008.

Table 1 reports the consequences of partisan parity, polarization, and hyper-competitive campaigns over the last half century of presidential elections. The last seven presidential elections (1988-2012) were typically decided by about half the margin of the previous seven elections (19601984). Four of the earlier seven elections were won with $55 \%$ or more of the two-party popular vote, but none of the more recent elections were won by margins that large. Presidential elections in the era of partisan parity and polarization have been closely fought battles and 2012 is among them.

The electorate's pre-campaign disposition toward the candidates in 2012 reinforced the context favoring a close election outcome. The two major indicators of precampaign public opinion indicated that the election could go either way. In mid-July, President Obama's presidential approval rating in the Gallup poll stood at $46 \%$. Of the ten incumbent presidents who sought reelection since 1956, six had higher mid-July approval ratings than President Obama and three had lower ratings. All six with higher ratings won. All three with lower ratings lost.

The pre-campaign presidential preference polls gave the same reading. In Gallup's pre-convention preference poll (released August 27, 2012), 46\% favored Obama and 47\% favored Romney. Obama's 49.5\% share of preferences ranked seventh of the ten incumbent presidents who had sought reelection since 1956. Of the six who had more support prior to the conventions, five won and one lost. Of the three who entered the fall campaign in a weaker poll position, only one won and two lost. In short, President Obama's reelection prospects, according to the historical association of the polls and election results, were up in the air.

\section{A Weak Economic Record}

While several of the fundamentals indicated that the election would be a toss-up, the economic record of the 
Obama presidency suggested otherwise. The economy favored Mitt Romney's election. Objective measures of the economy indicated that economic growth had been weak throughout President Obama's term, and there was little evidence that things were improving. Moreover, the poor state of the economy was understood by a large majority of voters.

Table 2 reports the mean economic growth rate in the real gross domestic product (GDP) over the course of presidential terms for the ten presidents who sought reelection since $1956 .{ }^{2}$ The economic records are ordered from the most to least growth. The reelection outcomes are also included. The growth rates are calculated from the beginning of the second year of a presidential term through the third-quarter of the reelection year (through September of the election year). Economic growth in the first year of a president's term is not counted to avoid conflating the effects of the previous president's policies with those of the current president (Campbell 2011; 2012).

There has been wide variation in economic performance of incumbents seeking reelection over this period, from the boom times of Kennedy and Johnson in the early 1960s to the sluggish economy in the mid-1970s under Nixon and Ford. It is also clear that the economy has mattered to election outcomes. Setting aside 2012, the six presidents presiding over economies growing at rates about $2.5 \%$ were each reelected, and the three presidents with more slowly growing economies lost. The correlation of the GDP growth rate for the term and the incumbent's vote, again excluding 2012, was impressively strong $(\mathrm{r}=0.86)$. While the number of cases is small, the pattern is clear. In the ranking of the economies for the last ten incumbents seeking reelection, the economy's performance under President Obama was the third worst. Seven economic records were better and two were worse. The two with weaker economic records both lost and one with even a slightly stronger record (Jimmy Carter) also lost.

An examination of the state of the economy on the eve of general election campaigns paints a similar picture. Table 3 reports the ranking of incumbents' economies for the second quarter of reelection years. Though more variable and covering a shorter time frame, it also has a close correspondence to the vote $(\mathrm{r}=0.67)$. Of the 11 presidential records in this ranking, Obama's record ranked ahead of only one, Jimmy Carter, who went on to lose to Ronald Reagan in 1980. Two other incumbents with second-quarter reelection year economies stronger than Obama's also were defeated.

2 Real GDP growth data are from the Bureau of Economic Analysis (2012).
Table 2 Economic growth over a president's term, 1956-2012.

\begin{tabular}{rlrl}
\hline Rank & President and re-election year & $\begin{array}{r}\text { GDP growth } \\
\text { over term, \% }\end{array}$ & $\begin{array}{l}\text { Election } \\
\text { outcome }\end{array}$ \\
\hline 1 & Kennedy/Johnson, 1964 & 5.2 & Won \\
2 & Ronald Reagan, 1984 & 4.1 & Won \\
3 & Dwight Eisenhower, 1956 & 3.5 & Won \\
3 & Bill Clinton, 1996 & 3.5 & Won \\
3 & Richard Nixon, 1972 & 3.5 & Won \\
6 & George W. Bush, 2004 & 2.9 & Won \\
7 & Jimmy Carter, 1980 & 2.3 & Lost \\
$\mathbf{8}$ & Barack Obama, 2012 & $\mathbf{2 . 1}$ & Won \\
9 & George H.W. Bush, 1992 & 1.8 & Lost \\
9 & Nixon/Ford, 1976 & 1.5 & Lost \\
\hline
\end{tabular}

Source: Bureau of Economic Analysis.

Note: Mean real GDP growth is based on the 10 quarters from Q1 of year 2 to $Q 3$ of year 4 .

The series starts with 1956 because of data availability.

Table 3 Economic growth in the second quarter of reelection years, 1948-2012.

\begin{tabular}{rlrl}
\hline Rank & $\begin{array}{l}\text { President and re-election } \\
\text { year }\end{array}$ & $\begin{array}{r}\text { GDP growth in } \\
\text { 2nd quarter, \% }\end{array}$ & $\begin{array}{l}\text { Election } \\
\text { outcome }\end{array}$ \\
\hline 1 & Richard Nixon, 1972 & 9.8 & Won \\
2 & Harry Truman, 1948 & 7.5 & Won \\
3 & Ronald Reagan, 1984 & 7.1 & Won \\
3 & Bill Clinton, 1996 & 7.1 & Won \\
5 & Lyndon Johnson, 1964 & 4.7 & Won \\
6 & George H.W. Bush, 1992 & 4.3 & Lost \\
7 & Dwight Eisenhower, 1956 & 3.2 & Won \\
8 & Gerald Ford, 1976 & 3.0 & Lost \\
9 & George W. Bush, 2004 & 2.6 & Won \\
10 & Barack Obama, 2012 & 1.3 & Won \\
11 & Jimmy Carter, 1980 & -7.9 & Lost \\
\hline
\end{tabular}

Source: Bureau of Economic Analysis.

The weak condition of the economy did not escape the voters' attention. By a wide margin, more voters in the exit polls named the economy to be the most important problem facing the nation (59\%-18\% for the next issue). They overwhelmingly said they thought the economy was in bad shape: $77 \%$ said that they thought the economy was "not so good" or "poor." A sizeable majority also thought that the economy was not improving or was even getting worse (55\%). Only $43 \%$ thought that the economy was "getting better" or was "good and staying the same." This corresponds to a flat line regression analysis of quarterly growth during Obama's term. ${ }^{3}$ Setting aside the first year

3 The regression used a counter variable for each quarter beginning in the first quarter of Obama's second year. The dependent variable was the quarterly growth in real GDP. The counter was not close to being statistically significant $(p<0.45)$ and the adjusted $R^{2}$ was zero. 
(2009), growth from the second year (2010) through the first half of the third year (2011) had been at a rate of $2 \%$. Average growth from that point through the third quarter of 2012 was about the same, $2.3 \%$.

Whether taking a broad view of the economic record or focusing in more narrowly on the economy as the general election campaign got underway, economic growth under President Obama was weak. Most presidents had stronger records, and those who did not had been sent packing. That said, it is also the case that incumbents normally run strong races even when they lose. They rarely lose badly. As one would expect, a regression analysis of the two series of economic readings in Tables 2 and 3 indicated that they favored Mitt Romney's election, but not by as much as one might think. Based just on how the economic records of previous incumbents matched up with their vote shares, even with what is by historical comparisons a poor economic record, President Obama was expected to receive about $48.8 \%$ of the two-party vote to $51.2 \%$ for his Republican challenger. ${ }^{4}$ Of course, this partially reflects the effects of incumbency (since the analysis includes just incumbents) as well as the economy.

There is a question about whether the myriad of nonpresidential influences on the economy should be taken into account in determining the influence of the state of the economy on a presidential election. International economic conditions, political obstacles such as obstructionist Congresses, energy crises, environmental disasters, and many other factors can affect economic policies and economic growth rates. Many of these are negative, though some are positive. However, as the strong correlation between the two economic indicators and the vote suggests, voters typically do not take these non-presidential influences on the economy into account. They do not conclude that the president has done a good job or a bad job, under the circumstances. They conclude that the president has done a good job or a bad job, period. To their everlasting praise, most voters do not attempt to be economists. They are not prone to parsing out why a president failed or succeeded. Of course, professional economists themselves are often not in agreement about the economic effects of presidential policies (recall Harry Truman's wish for a one-handed economist).

Hardcore partisans on either side, of course, are more willing to accept explanations or excuses for presidential

\footnotetext{
4 This is based on a regression of the two GDP growth rates in Tables 2 and 3 on the incumbent's two-party presidential vote share. The regression results were as follows: a constant of 39.98, a term GDP coefficient of $3.80(p<0.01)$, and a second-quarter reelection year GDP coefficient of $0.57(\mathrm{p}<0.02)$. The adjusted $\mathrm{R}^{2}$ was 0.87 and the standard error was 2.32 .
}

successes or failures that suit their predispositions. Take President Clinton's record, for example. Many Democrats explained the good economic growth in the Clinton years on his tax, trade, and stimulus policies. Many Republicans, on the other hand, attributed this growth to the Republican Congress that came to power in the 1994 midterm elections and to two economic bubbles (the dot com and housing speculations) that did not burst until his successor took office. For those not among the polarized partisans, however, results are what matter. It is the job of the president to deal with obstacles, political or economic, and to deliver results. Most voters judge them accordingly.

\section{First Party-Term Incumbency}

While the president's economic record as well as the ups and downs of the Obama and Romney campaigns, from the " $47 \%$ " video to Romney's stronger first-debate performance, along with the parties' efforts at voter turnout, all played important roles, the star of the 2012 presidential election show was presidential incumbency. More specifically, the major context that heavily tipped the election toward the reelection of President Obama was the electoral power of first party-term incumbency.

Incumbent presidents have many advantages over challengers (Fair 1978; Campbell 2000, 2008; Weisberg 2002; Mayhew 2008). Incumbents come pre-approved by voters. A majority of voters elected the incumbent 4 years earlier, and so the candidate had at one point passed the acceptability test for voters. Like everything else, no one likes to admit that they made a mistake. This and the electorate's aversion to risk with the challenger establish a pro-incumbent inertia. Beyond this, incumbents should have gained some experience on the job. They can also wrap themselves in the good will associated with the office they hold, the "Rose Garden Strategy." For instance, their leadership in national emergencies (see Hurricane Sandy in the last week of the 2012 campaign) scores points with the electorate.

Incumbents also have greater control of the agenda of issues and have some the power to guide national attention to favorable issues and away from unfavorable ones. They also generally have the advantage of being uncontested for their party's nomination. This is a major advantage, since it allows the incumbent essentially to get a head-start on the fall campaign while his challenger is fending-off rivals for his party's nomination. The Obama campaign certainly made good use of this advantage in its early campaign to portray Romney as an out-of-touch, heartless, callous businessman who knew and cared little about the problems of average Americans. 
Not all incumbents are equal, of course, and there are two very distinct types of presidential incumbents: the first party-term incumbent and the later party-term incumbent (Campbell 2000, 2008). First party-term incumbents are those who succeed a president of the opposite party (e.g., Clinton in 1992, G.W. Bush in 2000, and Obama in 2008). Later party-term incumbents are those who follow a president of the same party (e.g., Ford from Nixon in 1974, G.H.W. Bush in 1988). First party-term presidents stand a much better chance of reelection than later party-term incumbents.

In examining the relationship of presidential elections through time, Helmut Norpoth (1995) found evidence of an autoregressive cycle in presidential politics - evidence that a party's candidate would fare better to the extent that the party did well in the last election, but worse in the election before that. The optimal circumstance in this cycle is a first party-term president whose party lost the election before last, but then won the next election. This comported with the finding by Alan Abramowitz (1988) that an in-party presidential candidate of a party seeking a third party-term or more does not do as well in the election as one who is seeking a second party-term (that would be a first party-term incumbent).

Table 4 reports the won-loss records of in-party candidates since 1900. While later party-term incumbents have been no more likely to win than lose and in-party candidates in open seat elections (no incumbent running) have actually been more likely to lose than win (but not significantly given the small numbers), first party-term incumbents have nearly a perfect record. Of the twelve first party-term incumbents who have run for reelection since 1900, only one (Carter in 1980) lost. First party-term winners were McKinley in 1900, Wilson in 1916, Coolidge in 1924, Franklin Roosevelt in 1936, Eisenhower in 1956, Johnson in 1964, Nixon in 1972, Reagan in 1984, Clinton in 1996, George W. Bush in 2004, and now Obama in 2012. Regression analyses, controlling for the different partisan eras since 1900 (pro-Republican from 1900 to 1928, pro-Democratic from 1932 to 1964, and at parity from 1968 to the present), indicate that the first party-term advantage has been worth about $5.7 \%$ of the two-party vote. ${ }^{5} \mathrm{In}$ macro-political terms, this is huge.

5 This is based on a regression of first party-term variable (1 for a Democrat, -1 for a Republican, and 0 if there were no first party-term incumbent) on the Democratic candidate's share of the two-party popular vote. A control for partisan era was also included ( -1 for the Republican era from 1900 to 1928, 1 for the Democratic era from 1932 to 1964 , and 0 for the era of partisan parity from 1968 to the present). The regression results were as follows: a constant of 49.00, party era coefficient of $3.54(\mathrm{p}<0.02)$, and a first party-term coefficient of 5.67 ( $\mathrm{p}<0.01$ ). The adjusted $\mathrm{R}^{2}$ was 0.37 and the standard error was 6.08 .
Table 4 Incumbency and presidential election outcomes, 1900-2012.

\begin{tabular}{lrrr}
\hline In-party candidate status & \multicolumn{2}{c}{ Outcome for in-party } & Total \\
\cline { 2 - 3 } & Won & Lost & \\
\hline First party-term incumbents & $11(92 \%)$ & $1(8 \%)$ & 12 \\
Later party-term incumbents & $4(50 \%)$ & $4(50 \%)$ & 8 \\
Open seat elections & $3(33 \%)$ & $6(67 \%)$ & 9 \\
\hline
\end{tabular}

Note: An election outcome win is counted as an electoral vote victory.

The near invincibility of first party-term incumbents is probably most appreciated by reviewing the one case since 1900 in which a first party-term president lost. President Carter's reelection bid in 1980 is the exception that proves the rule. A first party-term president has to have just about everything go wrong for him, and in a spectacular way, in order to lose the election - and Carter did. As Tables 2 and 3 indicate, Carter's economy was weak and getting worse as the election approached. In the second quarter of 1980, the economy declined by nearly 8 percentage points. This is comparable to the Great Recession decline of 2008 (a fourth quarter decline of 9\%). Beyond this, "the misery index" (unemployment plus inflation) reached its peak of nearly 21 points in 1980 .

Things were no better on the foreign affairs front. Fifty-two Americans were held hostage in Iran by Islamist militants, and Carter appeared helpless to do anything about it. Things were so bad that Democrats divided over whether to re-nominate the president. President Carter barely survived a nomination battle with Senator Ted Kennedy. Yet despite this mountain of problems, President Carter led his Republican challenger Ronald Reagan in the polls even as late as late-October. As the Carter case demonstrates, voters will put up with a great deal before they are convinced to fire a first party-term president. The election is a choice, but it is a choice in which the challenger bears an enormous burden of proof for why the incumbent should be let go.

Why are first party-term incumbents so blessed? First, unlike other candidates, they can use both of the perennial campaign themes of change and stability. As incumbents, the stability theme is theirs, but they also have been in office for only a short time and can lay claim to the change theme as well. Their party has also not been in office so long that intra-party squabbles have intensified, and the out-party has not been out of power so long that they quickly set aside their internal party differences. The party of first party-term presidents also has not been in office so long that its agendas are depleted, and 
centrist voters may not be tired of them yet (as in, familiarity breeds contempt, and absence makes the heart grow fonder).

A particularly important advantage of the first partyterm incumbent is that unsolved or un-remediated problems can still be blamed on his predecessor. At no time has this been clearer than in 2012. While there were some signs that the electorate was becoming less pessimistic about the economy as the election approached (though they were evenly divided about whether the economy was headed into another recession), the economy was still in bad shape and voters knew it. This was not enough to sink President Obama's reelection bid, however, because many more voters continued to blame former President Bush for the nation's economic problems than President Obama.

The first party-term advantage came to life in former President Clinton's speech at the Democratic National Convention. In that speech, President Clinton told the delegates and the national television audience: "No president, no president - not me, not any of my predecessors - no one could have fully repaired all the damage that he (President Obama) found in just 4 years.” The first party-term advantage is also reflected in President Obama's response to a reporter's question about what grade he would assign himself for his handling of the economy. He responded that he would give himself "an incomplete." Presidents normally receive a grade from the electorate for their performance. First party-term presidents, however, are an exception. Voters gave President Obama his incomplete.

Table 5 reports the attribution of responsibility for the weak economy from two different polls conducted during the campaign and from the national exit polls. The results are quite consistent. President Bush was blamed for the weak economy by a majority of respondents in each case, while fewer than 40\% laid the principal blame with President Obama. Whether they were right or wrong, more voters saw the nation's economic difficulties as a continuation of the Great Recession that began on President Bush's watch than an anemic recovery for which President Obama should be held to account. Despite presiding over

Table 5 Responsibility for economic problems in 2012.

\begin{tabular}{lrrr}
\hline $\begin{array}{l}\text { Responsibility for the } \\
\text { economy }\end{array}$ & $\begin{array}{r}\text { August } \\
\text { poll }\end{array}$ & $\begin{array}{r}\text { September } \\
\text { poll }\end{array}$ & $\begin{array}{r}\text { Exit } \\
\text { poll }\end{array}$ \\
\hline President Obama & 32 & 38 & 38 \\
Former President Bush & 54 & 54 & 53 \\
Both/Neither/Unsure & 14 & 8 & 9 \\
\hline
\end{tabular}

Source: ABC News/Washington Post Poll. August 22-25, 2012. $\mathrm{n}=1,002$; CNN/ORC Poll. September 7-9, 2012. $\mathrm{n}=709$ likely voters; and National Exit Poll. a poor economy for nearly 4 years, exit polls also indicated that President Obama only trailed Governor Romney by a single percentage point on the question of which candidate could better handle the economy. Similarly, these exit polls indicated that voters who thought that the economy was the nation's most important issue favored Romney over Obama, but by only 4 percentage points $(51 \%-47 \%)$.

There is no question that presidents often inherit economic problems from their predecessors. Elsewhere I have reported research that indicates that economic conditions in the last two quarters of a president's term of responsibility (extending into the first year of the next president's term) are inherited economic conditions that can get a president off to a good start or make that start more problematic (Campbell 2011, 2012). Before the last two quarters of 2009, the recession was over, according to the National Bureau of Economic Research (2009), and while growth in the third quarter was weak (1.4\%), growth in the fourth quarter was healthy (4.0\%). From this standpoint, the continuing economic malaise would seem to be the result of an anemic recovery rather than a hang-over from a distant recession, but this was not how a majority of (noneconomist) voters saw it. As a first party-term president, President Obama got the benefit of the doubt.

\section{Here's What did not Happen}

In the aftermath of the 2012 election, many interpretations of the election made the rounds. Interpretations ranged from the more ideological (Democrats being more attuned or Republicans more tone-deaf to the thinking Americans) to the personal (Obama was more likeable, competent, or compassionate than Romney) to the strategical (the Obama campaign's early anti-Romney media blitz) to the tactical (the greater success of Democrats in their get-outthe-vote drive) to even the meteorological (the response to Hurricane Sandy in late October). There are merits in many of these explanations, though all play second-fiddle to the fundamental of incumbency. If Obama had been roundly blamed for the bad economy, no get-out-the-vote effort, anti-Romney attack ads, or hurricane response could have saved him.

One explanation in particular, though, should be addressed because it can lead to serious miscalculations about governing by both parties. Many assume that the reelection of a president entails support for that president's policies. This is not necessarily the case. The 2012 presidential election was clearly not a general endorsement of President Obama and the Democrats' 
ideological perspectives about governing. Voters may not have found them so objectionable as to rule out a second term, but this is not the same as approving of those perspectives.

While there were several issues on which the majority of voters sided with President Obama according to the exit polls (abortion, immigration, Medicare, and increasing taxes on higher incomes, though they also generally opposed tax increases to cut the budget deficit), their broad views regarding the extent of government were closer to Romney's. Table 6 presents the evidence. Despite its greater composition of minorities, despite the Democrats' superior get-out-the-vote efforts, despite the gender gap and everything else, the electorate that reelected President Obama was basically a moderately conservative group of voters. Though moderates were the modal category, voters in 2012 were much more likely to see themselves as conservatives than as liberals.

Lest one think this was merely symbolic, more agreed with the conservative statement that government was "doing too many things better left to businesses and individuals" than the liberal perspective that the government "should do more to solve problems." Of those voters who said that candidate values mattered most to their vote decision, 55\% voted for Romney to $42 \%$ for Obama. And finally, on the signature issue of President Obama's first term, Obamacare, $49 \%$ of voters favored repealing some or all of it, while only $44 \%$ favored leaving it alone or expanding it.

\section{The 8-Year Presidential Term}

When the dust settled on the 2012 presidential election, Democrats celebrated and Republicans mourned - and debated how they might adjust or modify their appeal for the next election. President Obama, as he entered into negotiations with Republicans over the "fiscal cliff" and efforts to bring budget deficits under control, was said to have renewed leverage because of his reelection.

Table 6 Ideological division of voters in 2012.

\begin{tabular}{lrr}
\hline Exit poll question & \multicolumn{2}{c}{ Voter response, \% } \\
\cline { 2 - 3 } & Conservative & Liberal \\
\hline Self-identification of ideological orientation & 35 & 25 \\
Government doing too much or too little & 51 & 43 \\
Shares my values (candidate choice) & 55 & 42 \\
Repeal some or all of Obamacare & 49 & 44 \\
\hline
\end{tabular}

Republicans were on the defensive. These interpretations of the 2012 election, both in what they mean for governing over the next few years and for electoral prospects beyond, are far overdrawn. Of course, political leverage or power is to a significant degree a matter of psychology, and if both sides believe the President is newly empowered and the Republicans have been set back, then they are. But the interpretation of the election on which these beliefs are based appears to be flawed.

President Obama was reelected largely because he was a first party-term incumbent and first party-term incumbents almost never lose. President Obama's economic record tested the limits of his incumbency advantage, so that his reelection shows just how substantial that advantage was. The Romney campaign had a very difficult task, something close to an impossible mission. Republicans thought that the incumbent was vulnerable, and he was, but just not quite enough. Seen from this perspective, the election's outcome is neither a reason for the Democrats to rejoice nor for the Republicans to bemoan. Democrats dodged a bullet, and Republicans just fell short of doing the near-impossible.

There is an important and interesting lesson to be learned from the 2012 election, as miserable and unimportant as it was. While one presidential election is generally treated like any other by voters, by the media, and by political pundits and consultants, they are not all the same. An election involving a first party-term incumbent is substantially different from other presidential elections, and of the 29 elections since 1900, 12 (41\%) have involved first party-term incumbents. Voters give first party-term incumbents a huge benefit of the doubt. Challengers to first party-term incumbents are not on a level playing field with these incumbents.

Rather than viewing presidential elections as independently decided 4-year terms, those involving a change in the presidential party might be better seen as entailing a de facto eight-year term with a midterm review (the first presidential reelection) in case anything goes seriously haywire. If an election is seen as a contract, the original election of a new presidential party is an 8-year contract with the voters having an option to terminate after four years. Unless voters exercise their option, it is a two-term deal.

It is important that candidates, their campaigns, the media, and all political observers understand this, both before and after the election. It is not clear that the Romney campaign did. Whether they recognized it or not, they faced a steep uphill battle. Their best bet for climbing that hill was to tie the incumbent to his economic record, and that required aggressively linking his economic, 
energy, regulatory, tax, and other policies to this record. For a brief moment, Romney's successful first-debate performance, it appeared that the campaign might follow this track. But then it grew cautious, and that is something a challenger to a first party-term incumbent cannot afford to do.

\section{References}

Abramowitz, Alan I. 1988. "An Improved Model for Predicting Presidential Outcomes.” PS: Political Science and Politics, 4: 843-847.

Abramowitz, Alan I. 2010. The Disappearing Center: Engaged Citizens, Polarization, and American Democracy. New Haven, $\mathrm{CN}$ : Yale University Press.

Abramowitz, Alan I. and Kyle L. Saunders 1998. "Ideological Realignment in the U.S. Electorate." Journal of Politics 60: 634-652.

Bureau of Economic Analysis 2012. "Gross Domestic Product: Percent Change from Preceding Period." Accessed November 25, 2012. http://www.bea.gov/national/index.htmgdp.

Campbell, James E. 2000. "The Science of Forecasting Elections." In: Before the Vote: Forecasting American National Elections, edited by James E. Campbell and James C. Garand. Thousand Oaks, CA: Sage Publications. pp. 169-187.

Campbell, James E. 2008. The American Campaign: U.S. Presidential Elections and the National Vote. 2nd ed. College Station, TX: Texas A\&M University Press.

Campbell, James E. 2010. “Explaining Politics, Not Polls: Examining Macropartisanship with Recalibrated NES Data." Public Opinion Quarterly 74 (4): (October), 616-642.

Campbell, James E. 2012. "The Economic Records of the Presidents: Party Differences and Inherited Economic Conditions." The
Forum: A Journal of Applied Research in Contemporary Politics 9 (1), article 7 (April), 1-29.

Campbell, James E. 2012. “The President's Economy: Parity in Presidential Party Performance.” Presidential Studies Quarterly 42 (4): (December), 811-818.

Fair, Ray C. 1978. "The Effects of Economic Events on Votes for President." Review of Economics and Statistics 60: 159-173.

Mayhew, David R. 2008. “Incumbency Advantage in U.S. Presidential Elections: The Historical Record.” Political Science Quarterly 123: 201-228.

National Bureau of Economic Research. 2010. "Announcement of June 2009 Business Cycle Trough/End of Last Recession." (September 10, 2010). Accessed November 25, 2012. http://www.nber.org/cycles/sept2010.html.

Norpoth, Helmut 1995. "Is Clinton Doomed: An Early Forecast for 1996.” PS: Political Science \& Politics 28: 1-7.

Real Clear Politics 2012. "2012 Republican Presidential Nomination: Polling Data." http://www.realclearpolitics. com/epolls/2012/president/us/republican_presidential_ nomination-1452.html. Accessed November 25, 2012.

Weisberg, Herbert F. 2002. "Partisanship and Incumbency in Presidential Elections." Political Behavior 24: 339-360.
James E. Campbell is a UB Distinguished Professor of Political Science at the University at Buffalo, SUNY and author of three books on American elections, including The American Campaign: U.S. Presidential Campaigns and the National Vote. He has also published more than 80 articles and book chapters on various aspects of American politics. Portions of this analysis also appear in "A First Party-Term Incumbent Survives: The Fundamentals in 2012," in Larry J. Sabato, ed., Barack Obama and the New America: The 2012 Election and the Changing Face of Politics (Lanham, MD: Rowman and Littlefield, 2013). 